\title{
Evaluation of Immunological Parameters in Pregnant Women: Low Levels of B and NK Cells
}

\section{Avaliação dos parâmetros imunológicos em mulheres gestantes: baixos níveis de células $B$ e NK}

Juliana Araújo de Carvalho Schettini ${ }^{1,2}$ Thomás Virgílio Gomes ${ }^{1}$ Claudeir Dias da Silva Júnior ${ }^{1}$ Sandra de Andrade Heráclio ${ }^{1}$ Isabela Cristina Coutinho de Albuquerque Neiva Coelho ${ }^{1}$ Leuridan Cavalcante Torres ${ }^{1}$

${ }^{1}$ Instituto de Medicina Integral Professor Fernando Figueira, Recife, PE, Brazil

2 Universidade Católica de Pernambuco, Recife, PE, Brazil

Address for correspondence Juliana Araújo de Carvalho Schettini, PhD, Rua dos Coelhos, 300, 50070-550, Recife, PE, Brazil (e-mail: julianaschettini@yahoo.com.br).

Rev Bras Ginecol Obstet 2019;41:213-219.

Abstract
Keywords
- B-lymphocytes
- NK cell
- T-Lymphocytes
- pregnancy
- immunophenotyping
- reference range

Resumo
Objective To describe the immunological and hematological reference intervals of low-risk pregnant women.

Methods A cross-sectional retrospective database analysis of a basic and translational study analyzing the hematological evaluation blood counts and immunophenotyping of TCD3 + , TCD4 +, TCD8 +, B, and natural killer (NK) cells of the peripheral blood in 79 low-risk pregnant women and of 30 control women from the state of Pernambuco, Brazil, was performed.

Results No significant differences were detected between the hematological profiles of the $2^{\text {nd }}$ and $3^{\text {rd }}$ trimesters. Nevertheless, the median level of $B$ cells decreased significantly in the $2^{\text {nd }}\left(174 \times 10^{3} \mu \mathrm{L} ; p<0.002\right)$ and $3^{\text {rd }}$ trimesters $\left(160 \times 10^{3} \mu \mathrm{L}\right.$; $p<0.001)$, compared with the control group $\left(296 \times 10^{3} \mu \mathrm{L}\right)$. Similarly, the median level of NK cells was lower in the $2^{\text {nd }}\left(134 \times 10^{3} \mu \mathrm{L} ; p<0.0004\right)$ and $3^{\text {rd }}$ trimesters $\left(100 \times 10^{3} \mu \mathrm{L}, p<0.0004\right)$, compared with the control group $\left(183 \times 10^{3} \mu \mathrm{L}\right)$. In contrast, relative TCD4+ and TCD8+ levels increased in the $2^{\text {nd }}$ and $3^{\text {rd }}$ trimesters compared with the controls (TCD4 $+: 2^{\text {nd }}$ trimester $=59 \% ; p<0.001 ; 3^{\text {rd }}$ trimester $=57 \% ; p<0.01$; control $=50 \%$; and TCD $8+: 2^{\text {nd }}$ trimester $=31 \% ; p<0.001 ; 3^{\text {rd }}$ trimester $=36 \% ; p<0.01$; control $=24 \%$ ).

Conclusion Low-risk pregnant women have $\sim 40 \%$ less B and NK cells in the peripheral blood, compared with non-pregnant women. These parameters may improve health assistance for mothers and contribute to define reference values for normal pregnancies.

Objetivo Descrever o intervalo de referência imunológico e hematológico de gestantes de baixo risco.

(D)Juliana Araújo de Carvalho Schettini's ORCID is https://orcid.org/ 0000-0002-7176-5284.

received

November 6, 2018

accepted

February 2, 2019
DOI https://doi.org/

10.1055/s-0039-1683903. ISSN 0100-7203.
Copyright $\odot 2019$ by Thieme Revinter

Publicações Ltda, Rio de Janeiro, Brazil
License terms

(c) (i) 


\section{Palavras-chave}

- linfócitos B

- células NK

- linfócitos T

- gravidez

- imunofenotipagem

- intervalo de referência
Métodos Realizou-se uma análise retrospectiva, de um estudo básico e translacional, analisando o perfil hematológico e a imunofenotipagem das células TCD3 + , TCD4 + , TCD8 + , B e natural killer (NK) do sangue periférico de 79 gestantes de baixo risco e de 30 mulheres (controles) do estado de Pernambuco, Brasil.

Resultados Não observamos diferenças significativas entre os perfis hematológicos do $2^{\circ}$ e $3^{\circ}$ trimestres. No entanto, houve redução das células $B$ no $2^{\circ}$ (média $=174$ $\left.\times 10^{3} \mu \mathrm{L} ; p<0,002\right)$ e no $3^{\circ}$ trimestres $\left(160 \times 10^{3} \mu \mathrm{L} ; p<0,001\right)$, comparado com o grupo controle $\left(296 \times 10^{3} \mu \mathrm{L}\right)$. A mediana das células NK foi menor no $2^{\circ}\left(134 \times 10^{3}\right.$ $\mu \mathrm{L} ; p<0,0004)$ e no $3^{\circ}$ trimestres $\left(100 \times 10^{3} \mu \mathrm{L} ; p<0,0004\right)$, comparado com o grupo controle $\left(183 \times 10^{3} \mu \mathrm{L}\right)$. Porém, o percentual de TCD4+ e de TCD8+ aumentou no $2^{\circ}$ e $3^{\circ}$ trimestres em relação aos controles $\left(\mathrm{TCD} 4+: 2^{\circ}\right.$ trimestre $=59 \%$; $p<0,001 ; 3^{\circ}$ trimestre $=57 \% ; p<0,01$; controle $=50 \%$; e TCD $8+: 2^{\circ}$ trimestre $=31 \% ; p<0,001 ; 3^{\circ}$ trimestre $=36 \% ; p<0,01$; controle $=24 \%$ ).

Conclusão Mulheres grávidas de baixo risco têm $\sim 40 \%$ menos células B e NK no sangue periférico em comparação com mulheres não grávidas. Estes parâmetros podem melhorar a assistência à saúde das mães e contribuir para a definição de valores de referência para gestações normais.

\section{Introduction}

Pregnancy (and its outcome) is affected by hematological parameters that are influenced by environmental, genetic, and hormonal factors. ${ }^{1-3}$ Many hematological changes occur during pregnancy due to hormonal variation. The total blood volume (red and white blood cell [WBC] mass) increases, while platelet counts decrease, especially in the $3^{\text {rd }}$ trimester. ${ }^{3,4}$ Alterations may occur in the maternal peripheral blood, in the composition of cellular subsets of the immune system and in the maternalfetal interface at the endometrial uterine wall. ${ }^{1,3}$

Invasion of allogenic fetal cells, vascularization (especially spiral arteries), and the formation of the placenta may cause inflammation at the maternal-fetal interface. ${ }^{5-7}$ Preventing a strong inflammatory response and ensuring maternal tolerance to the fetal semiallograft are essential for a normal pregnancy. ${ }^{5-7}$ In addition, the maternal immune system has to protect both the mother and the fetus from infections. ${ }^{8,9}$ Also during pregnancy, some hormones, including progesterone, estradiol, and human chorionic gonadotropin, modulate the immune system, being therefore essential for the maintenance of the pregnancy. ${ }^{10,11}$

Changes in the levels of several cell types (with different functional roles) during pregnancy have been well documented. These changes include the levels of TCD4+ cells and their effector subsets, such as Th1, Th2 and Th17, regulatory T cells (Treg), B cells, regulatory B cells (Breg) and natural killer (NK) cells, which together orchestrate the immune status of the system. ${ }^{5-9}$

There are several studies reporting the levels of T, B and NK cells during different pregnancy stages. ${ }^{12,13}$ However, most studies report the immunological profile (levels of T, B and NK cells) in high-risk pregnancies, such as those in which the pregnant woman presents with preeclampsia or gestational diabetes. ${ }^{14,15}$ Therefore, for these studies and for others that analyze the hematological and immunological profile of pregnant women, the reference values of cellular components of the immune system and hematological parameters of low-risk pregnant women are important in order to discriminate between healthy and unhealthy people and also to compare national and worldwide results.

The main purpose of the present study was to describe the immunological and hematological reference intervals during pregnancy. Therefore, we have performed a hematological evaluation (blood counts) and immunophenotyping of peripheral blood T cells $(\mathrm{CD} 3+, \mathrm{CD} 4+$, and $\mathrm{CD} 8+$ ), of B cells, and of NK cells in healthy low-risk pregnant women.

\section{Methods}

This was a cross-sectional retrospective database analysis of a basic and translational study performed at an outpatient pregnancy clinic (OPC) and at the Laboratório de Pesquisa Translacional of the Instituto de Medicina Integral Professor Fernando Figueira (IMIP) in Recife, state of Pernambuco, Brazil, between August 2013 and June 2014. The IMIP is the largest reference hospital for pregnant women in the northeast region of Brazil. The established clinical and laboratory protocols were submitted and approved by the IMIP Research Ethics Committee (protocol number 3437-13) and by the National Council of Scientific and Technological Development (CNPq, in the Portuguese acronym) $(\mathrm{CAAE}=12528213.8 .0000 .5201)$. Informed consent was signed by all of the participants.

\section{Study Population}

We have evaluated 79 Brazilian mothers (average age: 28 years old; age range: $18-41$ years old) recruited by the OPC-IMIP at the time of antenatal care. A total of $4 \mathrm{~mL}$ of maternal peripheral blood anticoagulated with ethylenediaminetetraacetic acid (EDTA) was collected for the automated blood count, which was performed with an Abbot Cell-Dyn 3700 hematology analyzer (Abbott Laboratories, Chicago, IL, USA). 
All of the participants were submitted to screening for the presence of human immunodeficiency virus (HIV), hepatitis B and $C$ viruses, human $T$ lymphotropic virus type 1 and 2, and to an antinuclear antibody test. None of the patients presented primary and/or secondary immunodeficiency. The inclusion criterion was low-risk single pregnancies in the $2^{\text {nd }}$ or $3^{\text {rd }}$ trimesters without any infectious diseases. None of the patients had clinical signs of infection during pregnancy and at the time of the peripheral blood collection. The exclusion criteria were (i) family or personal history of autoimmune diseases and/or positive antinuclear antibody test, (ii) infections, (iii) history of bone marrow or organ transplant, (iv) in vitro fertilization, (v) personal history of malignancy, and (vi) primary and/or secondary immunodeficiency. The controls were healthy fertile women with no signs of infection and who met the inclusion and exclusion criteria of the present study.

\section{Immunophenotyping of Total T, TCD4 + , TCD8 + , B, and Natural Killer Cells}

Four-color flow cytometric immunophenotyping of the peripheral blood was performed on a BD FACSVerse cytometer
(BD Biosciences, San Jose, CA, USA). The following monoclonal antibodies were used: anti-CD3, anti-CD4, anti-CD8, anti-CD16, anti-CD56, anti-CD19 and anti-CD20 (BD Biosciences, San Jose, CA, USA). The cells were analyzed using the most appropriate lymphocyte gate, with a combination of forward and side scatters ( - Fig. 1). The data obtained were analyzed using the BD FACSuite software (BD Biosciences, San Jose, CA, USA). The results were expressed as the percentage of positive cells within the selected gate. The mean fluorescence intensity index was used as measurement for the intensity of expression per cell.

\section{Statistical Analysis}

The statistical analysis was performed using the Prism 6 software, (GraphPad Software, San Diego, CA, USA). Data are presented as median, minimum and maximum, quartiles/ interquartile range (IQR) $\left(25^{\text {th }}-75^{\text {th }}\right.$ percentile $)$ and percentiles $\left(10^{\text {th }}\right.$ and $\left.90^{\text {th }}\right)$. The categorical variables are presented as percentage (\%). The nonparametric Mann Whitney U-test was used to compare quantitative variables of two independent groups. Statistical significance was established at $p<0.05$.

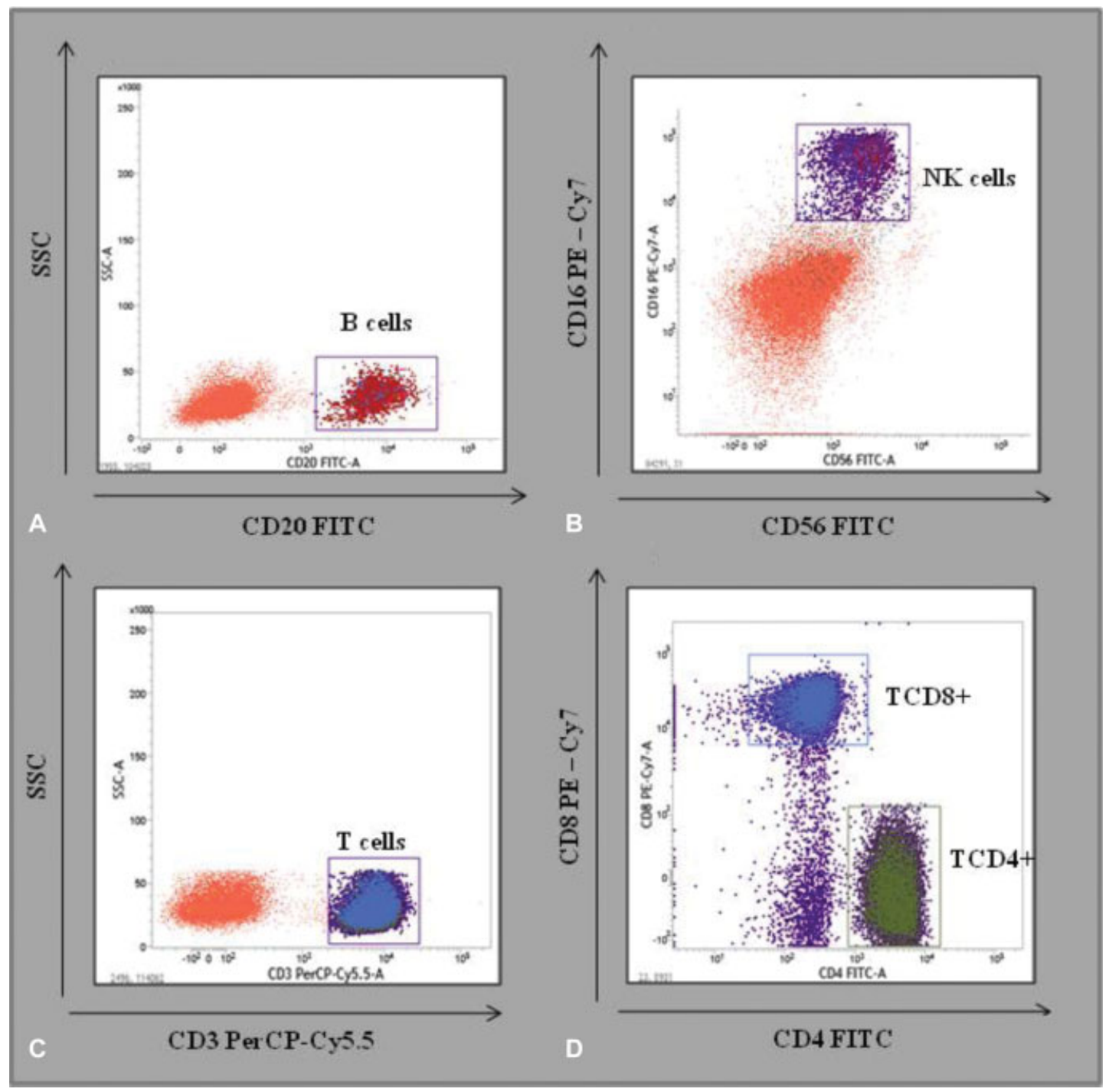

Fig. 1 Representative density plots showing analyzes of: A) B cells (CD20+); B) NK cells (CD56+; CD16+); C) T cells (CD3+); D) T cells (CD4+ and CD8+). 


\section{Results}

\section{Study Group}

The study sample was composed of 79 Brazilian mothers. The median age of the pregnant women who participated in the present study was 28 years old (range: $18-41$ years old). Most of the participants $(n=50)(63.2 \%)$ were in their $2^{\text {nd }}$ trimester, 29 (36.7\%) were in their $3^{\text {rd }}$ trimester, 45 (57\%) carried a female fetus, and 34 (43\%) carried a male fetus. Out of the total sample, $\sim 24 \%$ (19) were primiparous, $46.6 \%$ (37) were in the second pregnancy, $24 \%$ (23) had had 3 or more pregnancies, and $12.5 \%$ (10) had had a previous abortion. About $13 \%$ (10) of the pregnant women had completed secondary education, $47 \%$ (38) had completed primary education, 35\% (27) had incomplete primary education, and 5\% (4) had never studied. In the control group (non-pregnant women) the median age was 33 years old (range: 18-45 years old); 11\% (3) had completed secondary education, 44\% (13) had completed primary education, $40 \%$ (12) had incomplete primary education, and 5\% (1) had never studied. The number of pregnancies among the controls varied from 1 to 5 (median: 2 ), the parity varied from 0 to 3 (median: 1), and 4 of the controls (13\%) had had a previous spontaneous abortion. There was no statistically significant difference in height, weight, and body mass index (BMI) between the groups analyzed.

\section{Hematological Parameters}

There was no statistical difference in the median values of red cell (RCC), hematocrit (Htc), hemoglobin ( $\mathrm{Hb}$ ), total leucocytes, monocytes, neutrophils, eosinophils, basophils, lymphocytes, and platelets counts between the $2^{\text {nd }}$ and $3^{\text {rd }}$ trimesters $(p>0.05)$ ( $\mathbf{- T a b l e ~} \mathbf{1})$.

Immunological parameters: The immunophenotyping of Brazilian mothers during pregnancy is summarized in - Table 2. There was no statistical difference between lymphocyte subsets of the $2^{\text {nd }}$ and $3^{\text {rd }}$ trimesters $(p>0.05)$
( - Table 1). Low relative and absolute levels of $B$ cells ( $p<0.003$ and $p<0.001$ respectively) and low absolute levels of NK cells $(p<0.019)$ were observed. High relative levels of TCD4 $+(p<0.01)$ and of TCD8 + cells $(p<0.0004)$ were observed in the $2^{\text {nd }}$ and $3^{\text {rd }}$ trimesters, compared with the control group (-Table 2 ).

\section{Discussion}

The reference values of cellular components of the immune system and of the hematological parameters of low-risk pregnant women is important for antenatal care to discriminate between healthy and unhealthy people, and also to compare national and worldwide results. The use of reference intervals derived from non-Brazilian populations could lead to the misinterpretation of the laboratory test results and may result in incorrect clinical care for the pregnant women. We have found low P10 levels of RCC, Hct, Hb, leucocytes, neutrophils, lymphocytes, and of eosinophils in the $3^{\text {rd }}$ trimester. However, based on the median levels, we did not find any statistically significant difference in the hematological parameters between pregnant women in the $2^{\text {nd }}$ and $3^{\text {rd }}$ trimesters. In contrast, Akinbami et $\mathrm{al}^{2}$ reported an increase in WBCs counts between the $1^{\text {st }}$ and $3^{\text {rd }}$ trimester of pregnancy in Nigerian women. Some authors have also observed a decrease in platelets during the $3^{\text {rd }}$ trimester. $^{2,16}$ Also, Genetu et al ${ }^{16}$ found higher Hct and $\mathrm{Hg}$ levels as pregnancy advances in an Ethiopian population. Ethnic peculiarities and some environmental factors are involved in these differences.

However, pregnant women in their $2^{\text {nd }}$ and $3^{\text {rd }}$ trimesters had low relative and absolute levels of B lymphocytes. As previously described in an animal model, this could be due to the migration of $\mathrm{B}$ cells to the human decidua and their differentiation into Breg cells. Some authors have demonstrated that interleukin 10 (IL10) produced by Breg cells can support the expansion of Treg cells. ${ }^{17}$ The latter may, in turn,

Table 1 Hematological and Immunological parameters of Brazilian mothers in the $2^{\text {nd }}$ and the $3^{\text {rd }}$ trimesters of pregnancy

\begin{tabular}{|c|c|c|c|c|c|c|c|}
\hline & \multicolumn{3}{|c|}{$\begin{array}{c}2^{\text {nd }} \text { trimester } \\
(n=49)\end{array}$} & \multicolumn{3}{|c|}{$\begin{array}{c}3^{\text {rd }} \text { trimester } \\
(n=30)\end{array}$} & \multirow[b]{2}{*}{$p$-value } \\
\hline & Median & $\mathrm{P} 10^{\text {th }}-\mathrm{P} 90^{\text {th }}$ & IQR & Median & $\mathrm{P} 10^{\text {th }}-\mathrm{P} 90^{\text {th }}$ & IQR & \\
\hline $\mathrm{RCC}^{*}$ & 3,830 & $3,370-4,420$ & $3,635-4,410$ & 4,130 & $1,983-4,341$ & $3,585-4,200$ & 0.82 \\
\hline Hct (\%) & 35.3 & $30.7-39.5$ & $33.1-37.9$ & 35.7 & $28.22-39.89$ & $32.43-37.98$ & 0.42 \\
\hline $\mathrm{Hb}(\mathrm{g} / \mathrm{dl})$ & 11.8 & $10.5-13.1$ & $11.1-12.6$ & 12.1 & $9.28-13.31$ & $11.13-12.75$ & 0.69 \\
\hline Leucocytes** & 9.4 & $6.1-13.9$ & $7.4-10.5$ & 9.4 & $5.3-12.3$ & $7.2-10.55$ & 0.39 \\
\hline Neutrophils** & 6.6 & $4.3-9.7$ & $5.4-8.2$ & 6.5 & $3.7-8.7$ & $4.9-8.1$ & 0.39 \\
\hline Lymphocytes** & 1.7 & $1.2-2.9$ & $1.4-2.2$ & 1.7 & $1.0-2.6$ & $1.3-2.2$ & 0.30 \\
\hline Monocytes ${ }^{* *}$ & 0.5 & $0.2-0.8$ & $0.4-0.6$ & 0.6 & $0.27-0.84$ & $0.39-0.72$ & 0.33 \\
\hline Eosinophils ${ }^{* *}$ & 0.01 & $0.09-0.33$ & $0.11-0.25$ & 0.01 & $0.06-0.33$ & $0.09-0.16$ & 0.22 \\
\hline Basophils** & 0.02 & $0.010-0.063$ & $0.01-0.04$ & 0.02 & $0.045-0.087$ & $0.02-0.04$ & 0.95 \\
\hline Platelets** & 232 & $145-318$ & $196-291$ & 216 & $152-359$ & $182-267$ & 0.06 \\
\hline
\end{tabular}

Abbreviations: Hb: hemoglobin; Hct: hematocrit; IQR: interquartile range; RCC: red cell count.

${ }^{*}\left(\times 10^{6} / \mathrm{mL}\right) ;{ }^{* *}\left(\times 10^{3} / \mu \mathrm{l}\right)$; Data are expressed as median, interquartile ranges $(\mathrm{IQRs})$ and percentiles $\left(\mathrm{P} 10^{\text {th }}-\mathrm{P} 90^{\text {th }}\right) . P<0.05$ was considered statistically significant. 


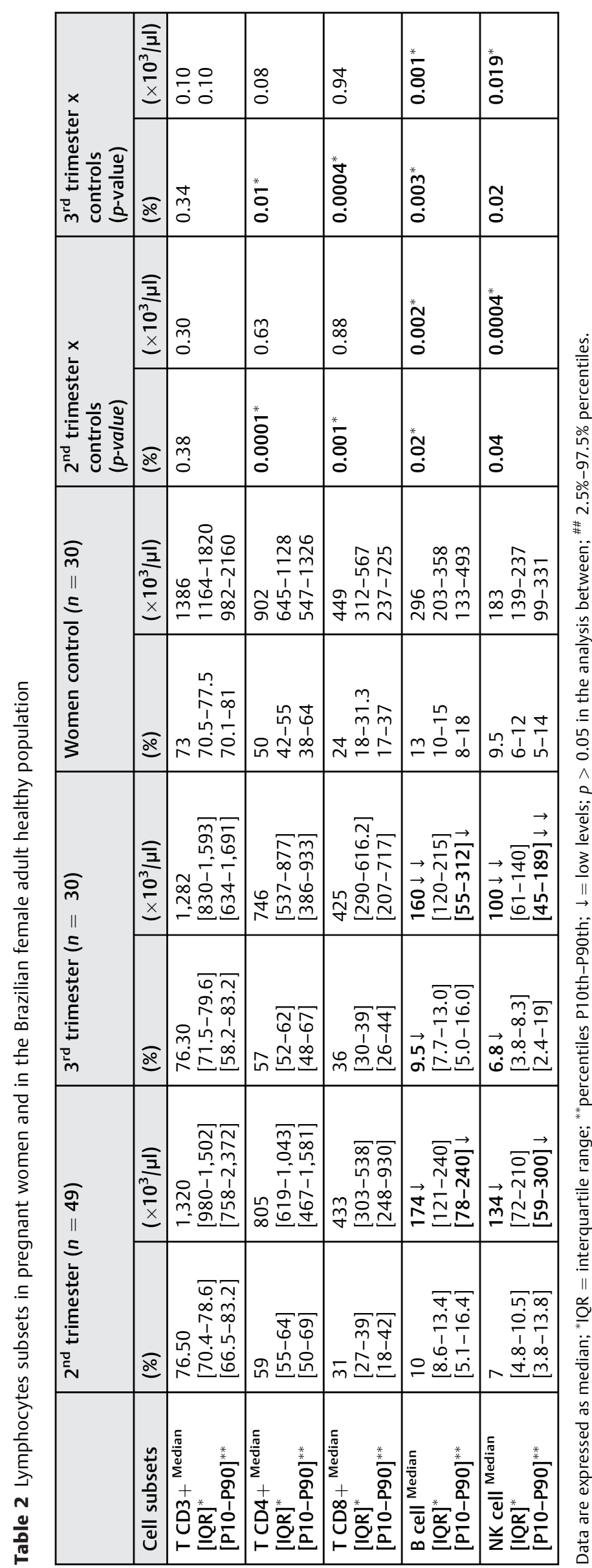


participate in the development of maternal-fetal tolerance and also maintain dendritic cells in an immature state, inhibiting their capacity to present antigens and, consequently, to activate T cells. ${ }^{17,18}$ Thus, low B cell counts in the peripheral circulation during pregnancy may be related to infiltration in the maternal-fetal interface, as described for animal models, affecting the maternal-fetal immune tolerance. Some authors reported that the number of conventional B cells remains relatively constant during human pregnancy. However, the maternal blood has lower proportions of B1 lymphocyte subsets during pregnancy, which return to nonpregnant women levels in the postpartum period. Levels of B2 cells remain unchanged in the maternal peripheral blood during pregnancy. ${ }^{19}$

Levels of NK cells decreased during the $2^{\text {nd }}$ and $3^{\text {rd }}$ trimesters of pregnancy compared with the control group. Contrasting the normal levels of NK cells in the peripheral blood, which account for a small fraction of the total lymphocytes $(\sim 10 \%)$, NK cells are the dominant cell type in the decidua during normal pregnancies $(\sim 50-90 \%) .{ }^{20}$ Interleukin 15 (IL-15), secreted by endometrial stromal cells, promotes migration of NK cells to the decidua. These cells have different functions: protection against infections (in the mother and in the fetus), angiogenesis, vascular remodeling (especially spiral arteries), and immune regulation. ${ }^{20,21}$ There are two specific subpopulations of NK cells with distinct functions: cytotoxic or regulatory cells.

Cytotoxic NK cells are important determinants of recurrent pregnancy loss, adherent placenta accreta, rate of embryo implantation in in vitro fertilization, complicated pregnancies due to hypertensive disorders such as preeclampsia, and intrauterine growth restriction. ${ }^{14,21-24}$ Furthermore, high levels of NK cells in the peripheral maternal blood may be associated with adverse maternal and perinatal outcomes. Regulatory NK cells (CD56 bright/CD16-) are required for trophoblast control, for vascular remodeling in the regulation of tissue homeostasis, and to prevent strong inflammatory maternal responses. ${ }^{5,25,26}$

In addition, decidual regulatory NK cells promote maternal immune tolerance to the fetus by regulating inflammatory Th17 cells at the maternal-fetal interface. ${ }^{6,8,25}$ There is no consensus in the literature on the levels of TCD4+ and of TCD8 + cells in the peripheral blood during pregnancy. ${ }^{5,26-28}$ However, high relative levels of TCD4+ and of TCD8+ cells in the peripheral blood of pregnant women are known to be important for the protection of the mother and of the fetus against bacterial and virus infections, caused for instance by arbovirus, adenovirus and HIV. ${ }^{29,30}$ Furthermore, it has been suggested that the increase in TCD4+ and in TCD8+ cell levels compensates for the lower levels of $\mathrm{B}$ and NK cells in the peripheral blood. We could not evaluate longitudinally the selected parameters in the $1^{\text {st }}, 2^{\text {nd }}$, and $3^{\text {rd }}$ trimester in all of the women and compare their concentrations among the trimesters because, unfortunately, there was a delay in the Brazilian public health system (SUS, in the Portuguese acronym) to confirm the antenatal consulting in the beginning of the pregnancy; however, this is a good objective for future research. We have found in the literature studies reporting the levels of T, B and NK cells during different pregnancy trimesters mainly in high-risk pregnancies, mostly from Europe and from the United States of America. However, the present study has been performed with low-risk pregnancies in South America. We have also analyzed the chemokines and cytokines of some pregnant women included in the population of the present study, and the data is free for consulting. ${ }^{31}$

Clinical and laboratory protocols were approved by the Research Ethics Committee of the IMIP (no. 3437-13). Written informed consent was obtained from all of the participants.

\section{Conclusion}

In conclusion, low levels of total B and NK cells in the peripheral blood indicate that these cell populations are important for immune balance during pregnancy. Further research on the levels of the regulatory subsets of B and NK cells in the placenta tissue and in the peripheral blood may contribute to our understanding of immune tolerance during pregnancy.

\section{Contributions}

All of the authors contributed with the project and the interpretation of data, the writing of the article, the critical review of the intellectual content, and with the final approval of the version to be published.

\section{Conflicts of Interest}

The authors have no conflicts of interest to declare.

\section{References}

1 Kumpel BM, Manoussaka MS. Placental immunology and maternal alloimmune responses. Vox Sang 2012;102(01):2-12. Doi: 10.1111/j.1423-410.2011.01533.x

2 Akinbami AA, Ajibola SO, Rabiu KA, et al. Hematological profile of normal pregnant women in Lagos, Nigeria. Int J Womens Health 2013;5:227-232. Doi: 10.2147/IJWH.S42110

3 Chandra S, Tripathi AK, Mishra S, Amzarul M, Vaish AK. Physiological changes in hematological parameters during pregnancy. Indian J Hematol Blood Transfus 2012;28(03):144-146. Doi: 10.1007/s12288-012-0175-6

4 Swanepoel AC, Pretorius E. Erythrocyte-platelet interaction in uncomplicated pregnancy. Microsc Microanal 2014;20(06): 1848-1860. Doi: $10.1017 /$ S1431927614013518

5 Fu B, Tian Z, Wei H. Subsets of human natural killer cells and their regulatory effects. Immunology 2014;141(04):483-489. Doi: 10.1111/imm.12224

6 Song D, Shi Y. Immune system modifications and feto-maternal immune tolerance. Chin Med J (Engl) 2014;127(17):3171-3180. Doi: 10.3760/cma.j.issn.0366-6999.20133072

7 Christiansen OB. Reproductive immunology. Mol Immunol 2013; 55(01):8-15. Doi: 10.1016/j.molimm.2012.08.025

8 Mor G, Cardenas I. The immune system in pregnancy: a unique complexity. Am J Reprod Immunol 2010;63(06):425-433. Doi: 10.1111/j.1600-0897.2010.00836.x

9 Zenclussen AC. Adaptive immune responses during pregnancy. Am J Reprod Immunol 2013;69(04):291-303. Doi: 10.1111/aji.12097

10 Schumacher A, Costa SD, Zenclussen AC. Endocrine factors modulating immune responses in pregnancy. Front Immunol 2014; 5:196. Doi: 10.3389/fimmu.2014.00196 
11 Polese B, Gridelet V, Araklioti E, Martens H, Perrier d'Hauterive S, Geenen V. The endocrine Milieu and CD4 T-lymphocyte polarization during pregnancy. Front Endocrinol (Lausanne) 2014;5:106. Doi: 10.3389 /fendo.2014.00106

12 Köhler C, Adegnika AA, van der Linden R, Luty AJ, Kremsner PG. Phenotypic characterization of mononuclear blood cells from pregnant Gabonese and their newborns. Trop Med Int Health 2011;16 (09):1061-1069. Doi: 10.1111/j.1365-3156.2011.02812.x

13 Zhao Y, Dai ZP, Lv P, Gao XM. Phenotypic and functional analysis of human $T$ lymphocytes in early second- and third-trimester fetuses. Clin Exp Immunol 2002;129(02):302-308. Doi: 10.1046/j.13652249.2002.01920.x

14 Shields CA, McCalmon M, Ibrahim T, et al. Placental ischemiastimulated T-helper 17 cells induce preeclampsia-associated cytolytic natural killer cells during pregnancy. Am J Physiol Regul Integr Comp Physiol 2018;315(02):R336-R343. Doi: 10.1152/ ajpregu.00061.2018

15 Gomes Fagundes DL, França EL, da Silva Fernandes RT, et al. Changes in T-cell phenotype and cytokines profile in maternal blood, cord blood and colostrum of diabetic mothers. J Matern Fetal Neonatal Med 2016;29(06):998-1004. Doi: 10.3109/14767058.2015.1031739

16 Genetu M, Damtie D, Workineh M, Mathewos Tebeje B, Enawgaw B, Deressa T. Immunological and hematological reference intervals among HIV-seronegative pregnant women in northwest Ethiopia. Int JWomens Health 2017;9:145-150. Doi: 10.2147/IJWH.S126916

17 Jensen F, Muzzio D, Soldati R, Fest S, Zenclussen AC. Regulatory B10 cells restore pregnancy tolerance in a mouse model. Biol Reprod 2013;89(04):90. Doi: 10.1095/biolreprod.113.110791

18 Muzzio DO, Soldati R, Ehrhardt J, et al. B cell development undergoes profound modifications and adaptations during pregnancy in mice. Biol Reprod 2014;91(05):115. Doi: 10.1095/ biolreprod.114.122366

19 Bhat NM, Mithal A, Bieber MM, Herzenberg LA, Teng NN. Human CD5+ B lymphocytes (B-1 cells) decrease in peripheral blood during pregnancy. J Reprod Immunol 1995;28(01):53-60. Doi: 10.1016/0165-0378(94)00907-0

20 Koopman LA, Kopcow HD, Rybalov B, et al. Human decidual natural killer cells are a unique NK cell subset with immunomodulatory potential. J Exp Med 2003;198(08):1201-1212. Doi: 10.1084/jem.20030305

21 Roussev RG, Dons'koi BV, Stamatkin C, et al. Preimplantation factor inhibits circulating natural killer cell cytotoxicity and reduces CD69 expression: implications for recurrent pregnancy loss therapy. Reprod Biomed Online 2013;26(01):79-87. Doi: 10.1016/j.rbmo.2012.09.017

22 Laban M, Ibrahim EA, Elsafty MS, Hassanin AS. Placenta accreta is associated with decreased decidual natural killer (dNK) cells population: a comparative pilot study. Eur J Obstet Gynecol Reprod Biol 2014;181:284-288. Doi: 10.1016/j.ejogrb.2014. 08.015

23 Thum MY, Bhaskaran S, Abdalla HI, et al. An increase in the absolute count of CD56dimCD16+CD69+ NK cells in the peripheral blood is associated with a poorer IVF treatment and pregnancy outcome. Hum Reprod 2004;19(10):2395-2400. Doi: 10.1093/humrep/deh378

24 Wallace AE, Fraser R, Gurung S, et al. Increased angiogenic factor secretion by decidual natural killer cells from pregnancies with high uterine artery resistance alters trophoblast function. Hum Reprod 2014;29(04):652-660. Doi: 10.1093/humrep/deu017

25 Fu B, Li X, Sun R, et al. Natural killer cells promote immune tolerance by regulating inflammatory $\mathrm{TH} 17$ cells at the human maternal-fetal interface. Proc Natl Acad Sci U S A 2013;110(03): E231-E240. Doi: 10.1073/pnas.1206322110

26 Luppi P, Haluszczak C, Trucco M, Deloia JA. Normal pregnancy is associated with peripheral leukocyte activation. Am J Reprod Immunol 2002;47(02):72-81. Doi: 10.1034/j.1600-0897.2002.10041.x

27 Kühnert M, Strohmeier R, Stegmüller M, Halberstadt E. Changes in lymphocyte subsets during normal pregnancy. Eur J Obstet Gynecol Reprod Biol 1998;76(02):147-151. Doi: 10.1016/S0301-2115 (97)00180-2

28 Watanabe M, Iwatani Y, Kaneda T, et al. Changes in T, B, and NK lymphocyte subsets during and after normal pregnancy. Am J Reprod Immunol 1997;37(05):368-377. Doi: 10.1111/j.16000897.1997.tb00246.x

29 Galluzzo C, Liotta G, Andreotti M, et al. Emergence of lamivudine resistance hepatitis $\mathrm{B}$ virus mutations in pregnant women infected with HBV and HIV receiving antiretroviral prophylaxis for the prevention of mother-to-infant transmission in Malawi. J Med Virol 2012;84(10):1553-1557. Doi: 10.1002/jmv.23365

30 Silasi M, Cardenas I, Kwon JY, Racicot K, Aldo P, Mor G. Viral infections during pregnancy. Am J Reprod Immunol 2015;73(03): 199-213. Doi: 10.1111/aji.12355

31 Schettini JAC, Gomes TV, Santos Barreto AK, et al. High levels of CXCL8 and low levels of CXCL9 and CXCL10 in women with maternal RhD alloimmunization. Front Immunol 2017;8:700. Doi: 10.3389/fimmu.2017.00700 